\title{
Influence of Hydrogen on Fracture Mode API X60 Steel
}

\author{
G. González-Mancera ${ }^{1}$, Cortés-Suárez V. ${ }^{2}$, Mariano-Alberto M. ${ }^{2}$ \\ ${ }^{1}$ Depto. Ing. Metalúrgica Fac. Química, Universidad Nacional Autónoma de México, Ciudad \\ Universitaria, México, D.F., 04510 \\ ${ }^{2}$ Depto. Materiales, Universidad Autónoma Metropolitana-Azcapotzalco, Av. San Pablo 180, México \\ D.F., 02200.
}

One of the applications of High Strength Low Alloy (HSLA) steel is its use in the manufacture of pipelines for transporting petroleum and its derivatives products [1]. These hydrocarbons produce hydrogen from hydrogen sulfide decomposition. Thus, hydrogen generated in the steel diffuses to regions such as grain boundaries, nonmetallic inclusions and other crystalline defects, and results in an embrittling effect, causing premature failure of the material [2]. The manufacture of HSLA steel involves getting a variety of microstructures which are produced from the transformation of austenite to phases such as ferrite, pearlite, and intermediate stages like bainite, martensite and acicular ferrite [3]. Intermediate stages can be obtained when the steel is subjected to high temperatures for long periods of time; conditions that promote the steel undergoes aging. Also, during welding, the melting zone shows a mix of microstructures. Each microstructure has a characteristic resistance to hydrogen embrittlement.

Purpose of this paper is to determine the hydrogen effect on the fracture mode. Therefore, the microstructure and the fracture mode were compared between a control API X60 steel annealed at $650{ }^{\circ} \mathrm{C}$ and steel containing hydrogen, and aged at $315{ }^{\circ} \mathrm{C}$ and $650{ }^{\circ} \mathrm{C}$. Hydrogen was introduced in these steels through cathode charged by applying a current density of $50 \mathrm{~mA} / \mathrm{cm}^{2}$. After hydrogen charging, the specimens were tested in tension at a deformation rate of $10^{-4} / \mathrm{s}$. And finally, SEM study was performed, to reveal the microstructure, and fracture surface of tested specimens.

Results in Figure 1 (a) exhibits equiaxed microstructure with grains of polygonal ferrite corresponding to the annealing treatment. In contrast, the steel aged at $315^{\circ} \mathrm{C}$ exhibited a mixture of steel microstructures of acicular ferrite, bainite and martensite as observed in Figure 1 (b). The steel treated at $650{ }^{\circ} \mathrm{C}$ exhibited grains of polygonal ferrite and acicular ferrite (Figure $1 \mathrm{c}$ ).

In addition, this study reavealed three different fracture modes in APIX60 steel. Annealed steel presents fracture mechanism caused by coalescence of pores (Figure 2 a), indicating that the fracture is ductile. Steel aged at $315^{\circ} \mathrm{C}$ has intergranular fracture facets and cleavage (Figure $2 \mathrm{~b}$ ), which is characteristic of brittle fracture. In contrast, the specimen aged at $650{ }^{\circ} \mathrm{C}$ with dissolved hydrogen, has a mixed fracture mode (Figure $2 \mathrm{c}$ ). In this study, we determined that steel APIX60 aged causes fracture changes from ductile to brittle. In particular, the steel aged at $315^{\circ} \mathrm{C}$ has the least resistance to hydrogen damage.

\section{References:}

[1] Pickering, F.B., Microalloying 75 (1977), p. 9

[2] Ren, X.C., et al.,Metallurgical and Materials Transactions A 39,(2008), p. 87-97 
[3] A.S. Sinha, Physical Metallurgy Handbook, Mc Graw Hill 15 (2002)
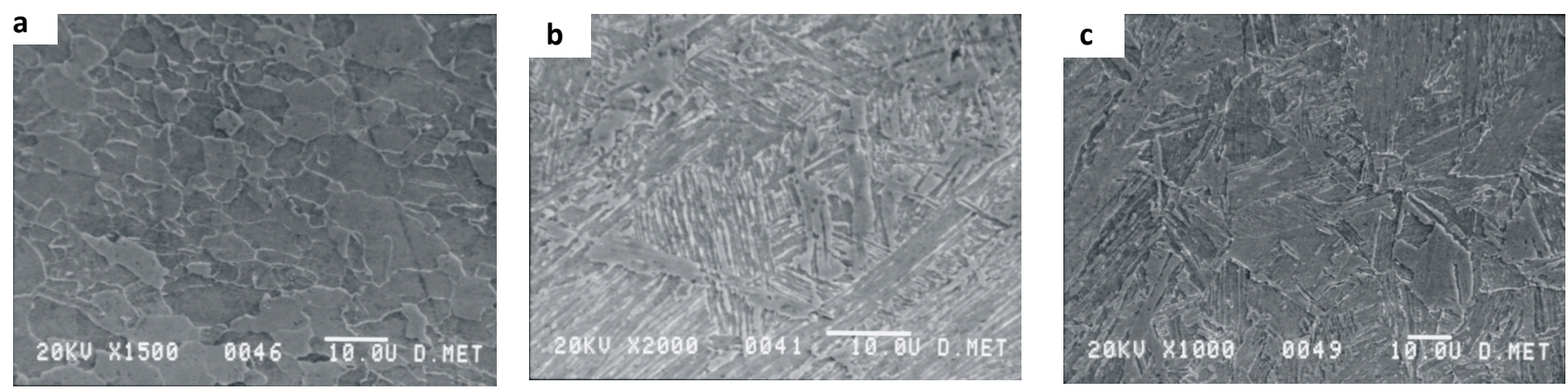

Figure 1. SEM images from API X60 steel pieces. 1 (a) Control sample annealed at $650{ }^{\circ} \mathrm{C} .1$ (b) Specimen aged to $315^{\circ} \mathrm{C}$ shows mixture of microstructures consisting of acicular ferrite, bainite and martensite from. 1 (c) Steel aged at $650{ }^{\circ} \mathrm{C}$ reveals microstructure consisting of acicular ferrite and polygonal ferrite grains
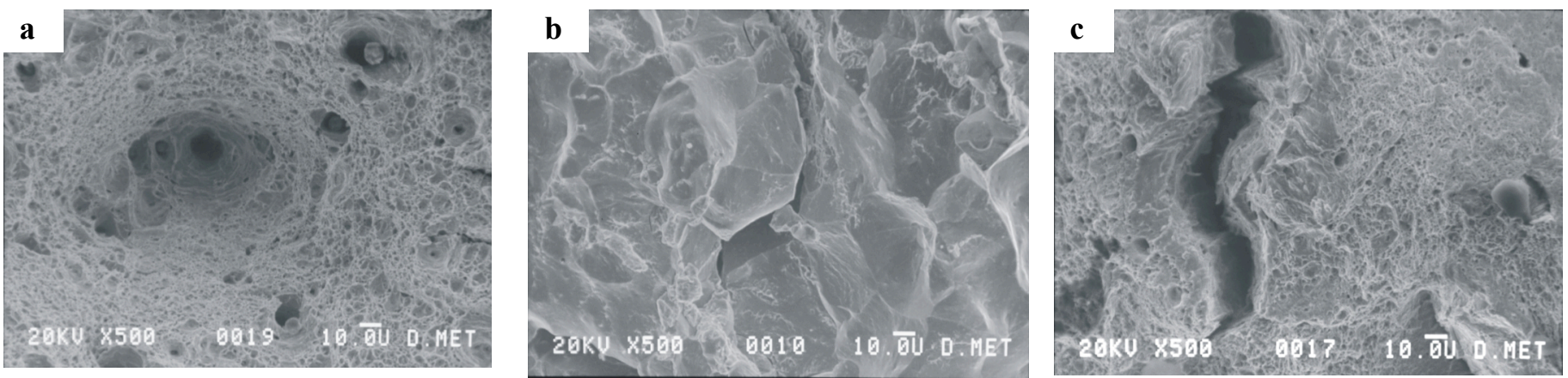

Figure 2. SEM micrographs, of the fracture mode from API X60 steel samples. 2 (a) Annealed sample at $650{ }^{\circ} \mathrm{C}$ shows coalescence of pores and ductile fracture. 2 (b) Steel aged at $315^{\circ} \mathrm{C}$ presents brittle fracture. 2 (c) Specimen aged at $650{ }^{\circ} \mathrm{C}$ displays a mixed mode fracture. 